Personalidade Acadêmica Homenageada:

Augustus B. Cochran III (Agnes Scott College)

\title{
A ÉTICA AMBIENTAL: A BUSCA PARA UMA SUSTENTABILIDADE EFETIVA
}

\section{ENVIRONMENTAL ETHICS: THE SEARCH FOR EFFECTIVE SUSTAINABILITY}

\section{LUIZ HENRIQUE SANTOS DA CRUZ}

Mestrando em Direito Empresarial e Cidadania no Programa de Mestrado do Centro Universitário Curitiba- UNICURITIBA PR; Bolsista Integral da Coordenação de Aperfeiçoamento Pessoal de Nível Superior - CAPES no Programa de Mestrado do UNICURITIBA- PR; Estudante de Pós-Graduação em Registros Públicos pela Universidade Cândido Mendes. UCAM- RJ; Graduado em Direito pela UNIVERSIDADE PARA O DESENVOLVIMENTO DO ALTO VALE DO ITAJAÍ UNIDAVI- Rio do Sul - SC (2004); Monitor na disciplina Direito Empresarial e Cidadania no Curso de Direito do Centro Universitário Curitiba- UNICURITIBA- PR; Monitor do Grupo de Pesquisa Direito Empresarial e Cidadania no Século XXI; Integrante do Grupo de Pesquisa Sustentabilidade e Direito; Integrante do Grupo de Pesquisa Direito e Saúde; Mediador judicial do Tribunal de Justiça do Estado do Rio de Janeiro; Graduado em Bacharel em Teologia pela Faculdade Teológica de Gramado- RS (1990); Advogado nas áreas trabalhistas, cível, consumidor e empresarial

\section{ELOIZA SACRAMENTO}

Mestranda em Direito Empresarial e Cidadania no UNICURITIBA; Especialista em Segurança Pública; Especialista em Docência no Ensino Superior; Mediadora e Conciliadora inscrita no CNJ; Perita Grafotécnica; Perita Judicial e Advogada Criminalista inscrita na OAB/PR. 


\section{Personalidade Acadêmica Homenageada:}

\section{Augustus B. Cochran III (Agnes Scott College)}

\section{RESUMO}

O presente resumo tem como objetivo estudar as cinco dimensões distintas que envolvem a ética ambiental, quais sejam: social, ética, jurídico-política, econômica e ambiental e quais seus impactos em um ambiente sustentável Importante destacar inicialmente que, o ambiente é uma disciplina e um campo de reflexão relativamente nova, de igual modo, os conceitos relacionados com a Ética Ambiental são também recentes. Importante observar que, a ética é um campo de estudo cuja origem se perde no tempo, o que possibilita uma melhor compreensão da gênese e da evolução da Ética Ambiental. Através da observação, pode se constatar que, a crise que se vive atualmente é, em essência, uma crise ética, quer dizer, de valores, que está profundamente ligada ao modo como o homem se relaciona com o seu mundo natural. Assim, ética e sustentabilidade caminham juntas, devem ser encaradas de maneira multidimensional, sendo composta de cinco dimensões distintas, quais sejam: social, ética, jurídico-política, econômica e ambiental. $O$ fato de o principal objetivo da ciência e da técnica ter se focado na necessidade do domínio da natureza, a emergência da ética ambiental trouxe a obrigatoriedade a forma de se repensar o caminho da humanidade, traçado pela modernidade. Os objetivos são pesquisar as cinco dimensões distintas que envolvem a ética ambiental, quais sejam: social, ética, jurídico-política, econômica e ambiental e quais seus impactos em um ambiente sustentável conforme disposto no Art. 225: "Todos têm direito ao meio ambiente ecologicamente equilibrado, bem de uso comum do povo e essencial à sadia qualidade de vida, impondo-se ao poder público e à coletividade o dever de defendê-lo e preservá-lo para as presentes e futuras gerações". A metodologia será bibliográfica e descritiva, ou seja, descrever as características, uma experiência ou um fenômeno, estabelecer uma relação entre os fatores do tema analisado. Esses fatores são a classificação, medida e/ou quantidade e todos podem sofrer alterações, reflexos durante o processo. Espera-se identificar que, de que maneira o agir de forma ética com meio ambiente é um dever de todos os atores da sociedade, bem como seus efeitos em uma sustentabilidade concreta e efetiva. $O$ trabalho não conclusivo pretende demonstrar que agir de forma 
Personalidade Acadêmica Homenageada:

Augustus B. Cochran III (Agnes Scott College)

ética é possível. A Sustentabilidade, por sua vez, é o resultado das ações humanas fundadas na ética e tem por base a transversalidade social, ética, jurídico-política, econômica e ambiental.

De acordo com este entendimento, Wolkmer e Paulitsch alegam que:

[...] a Ética Ambiental pode ser considerada como aquela que advém da necessidade de reexaminarmos nossos valores e princípios em razão dos problemas ambientais e à necessidade de compreendermos as razões que definem a relação do homem com a natureza. Não basta um despertar da consciência individual, necessitamos uma redefinição do quadro ético." (2011).

"conjunto de princípios que asseguram que nenhum grupo de pessoas, sejam grupos étnicos, raciais ou de classe, suporte (ACSELRAD, 2004).

PALAVRA-CHAVE: Inteligência Artificial; Sistemas Jurídicos; Celeridade Processual; Juiz Eletrônico.

\section{REFERÊNCIAS}

ACSELRAD, Henri. Conflitos ambientais no Brasil. Rio de Janeiro: Relume Dumará, 2004a, p.13-35.

. "As práticas espaciais e o campo dos conflitos ambientais". In: .Justiça ambiental: ação coletiva e estratégias argumentativas". In:

ACSELRAD, Henri et al. (Org.). Justiça ambiental e cidadania. 2. ${ }^{a}$ ed. Rio de Janeiro: Relume Dumará, 2004b, p.23-39.

WOLKMER, Maria F. S.; PAULITSCH, Nicole S. Ética Ambiental E Crise Ecológica: reflexões necessárias em busca da sustentabilidade. In: Veredas do Direito, Belo Horizonte, v.8, n.16, p.211-233, Julho/Dezembro de 2011. 